\title{
Plasma Glucagon Immunoreactivity in a Totally Pancreatectomized Patient*
}

\author{
M. L. Villanueva, J. A. Hedo and J. Marco \\ Clínica Puerta de Hierro, Universidad Autónoma de Madrid, Madrid, Spain
}

Summary. Analysis of the plasma from a totally pancreatectomized patient, with antiserum $30 \mathrm{~K}$, has demonstrated basal glucagon immunoreactivity (GIR) levels in the normal range $(80-110 \mathrm{pg} / \mathrm{ml})$. Neither i. $v$. arginine nor oral glucose affected these GIR values, thus indicating the absence of functioning pancreatic or gastrointestinal A-cells. Furthermore, filtration of whole plasma on Bio Gel P-30 showed no GIR in the $3500 \mathrm{MW}$ elution volume. GIR was found to be distributed in two peaks. One peak eluted in the protein region, similarly to "big plasma glucagon" (BPG), and the second peak appeared after the glucagon- $\mathrm{I}^{125}$ marker. The protein-sized moiety was not absorbable by charcoal, and on Sephadex G-100 it eluted within the globulin region. When subjected to trypsin treatment, it yielded smaller GIR fractions. According to these criteria, it can be assumed that this component is identical to BPG. Therefore, an extrapancreatic source for BPG is suggested. On the other hand, the presence of fasting hyperglycaemia in this patient indicates that insulin deficiency by itself suffices to raise blood sugar to diabetic levels.

Key words: Pancreatectomized patient, glucagon immunoreactivity, hyperglycaemia, arginine, glucose, gel filtration.

The existence of a glucagon-immunoreactive component in the globulin fraction of human plasma has been recently reported $[1,2]$. This component was

\footnotetext{
* Presented at the 35th Annual Meeting of the American Diabetes Association, June 17, 1975, New York, N. Y., U. S. A.

Supported in part by a research grant (12-894-74) from the Instituto Nacional de Previsión, Spain, by a research contract (No. 1551/RB) from the International Atomic Energy Agency, Vienna, Austria, and by a gift from the Alexander von Humboldt Stiftung, Bonn-Bad Godesberg, Federal Republic of Germany
}

initially detected in peripheral blood and, hence, provisionally termed "big plasma glucagon" (BPG). However, a glucagon-immunoreactive fraction with an elution volume similar to that of BPG was also demonstrated in extracts of dog pancreas and of isolated mouse pancreatic islets, leading to the suggestion that BPG might be a secretory product of the A-cell [1].

On the other hand, several groups have made the intriguing observation of normal or elevated circulating glucagon in totally depancreatized dogs $[3,4,5,6]$ and even in pancreatectomized eviscerated rats [7], as determined with specific antisera.

In this work, we have studied the glucagon immunoreactivity (GIR) plasma levels - basal, in response to arginine and to glucose - in a completely pancreatectomized patient, and its chromatographic pattern was examined by gel filtration. GIR was analyzed with antiserum $30 \mathrm{~K}$ (kindly donated by $\mathrm{Dr}$. R. H. Unger), considered to be specific for true glucagon, either pancreatic or extrapancreatic [8].

\section{Materials and Methods}

The patient was a 45 year old male (weight $=63 \mathrm{~kg}$; height $=172 \mathrm{~cm}$ ). He underwent duodenopancreatectomy with resection of the gastric antrum and Billroth II reconstruction three years prior to the study, due to intractable pain from chronic pancreatitis. He was receiving 30 units of NPH insulin (20 in the morning and 10 in the late evening) and pancreatic enzymatic replacement. He was left without insulin for $24 \mathrm{~h}$ prior to the tests, performed at 9:00 a. m.

Arginine hydrochloride (Arginina, Hermes, $10 \%$ solution) was infused intravenously at a dose of 468 $\mathrm{mg} / \mathrm{kg}$ over a ten-minute period. The oral glucose 
tolerance test (OGTT) was performed by administering $1.75 \mathrm{~g} / \mathrm{kg}$ glucose $(25 \%$ solution) in five minutes. The collection and processing of blood samples has been previously described [9]. Some plasma specimens were analyzed for GIR after treatment with a mixture of charcoal-dextran as described by Weir et al. [10]. Circulating GIR was further characterized by molecular-sieve chromatography. In addition, a globulin preparation obtained by ammonium sulphate precipitation of this patient's plasma was subjected to trypsin treatment for subsequent gel chromatography. These methods have been described in detail elsewhere [1]. GIR was estimated radioimmunologically by a charcoal separation method [11].

\section{Results}

In this patient, fasting blood sugar was $218 \mathrm{mg} / 100$ $\mathrm{ml}, 240 \mathrm{mg} / 100 \mathrm{ml}$ and $252 \mathrm{mg} / \mathrm{ml}$ on three different days. His basal plasma GIR levels, as measured with antiserum $30 \mathrm{~K}$, oscillated between 80 and $110 \mathrm{pg} / \mathrm{ml}$, well within the range corresponding to normal subjects found in our laboratory [9]. Neither i. v. arginine nor oral glucose altered circulating GIR concentrations. Mention should be made that in charcoaltreated plasma, GIR estimation yielded values from 50 to $80 \mathrm{pg} / \mathrm{ml}$.

Figure 1 illustrates the fractionation on Bio Gel P-30 of the GIR present in the basal plasma of this patient. No immunoreactivity could be detected in the zone of true glucagon, shown by the glucagon- $\mathrm{I}^{125}$ marker. Large glucagon immunoreactivity (LGI), the fraction with an estimated MW of 9000 [12], was also not found. The glucagon immunoreactivity appeared distributed in two peaks. One peak was observed in the protein region, with an elution volume similar to that of BPG of normal subjects. In a series of chromatograms this fraction accounted for 50 to 90 per cent of the recovered GIR. The second peak ran beyond the radioactive glucagon marker, similarly to the so-called fraction IV described by Valverde et al. [1]; its estimated MW is about 2000. An identical chromatographic pattern was found in samples obtained after arginine or glucose administration.

To obtain further information about the elution volume of the protein-sized glucagon-immunoreactive fraction, plasma of this patient was filtered through Sephadex G-100. On this gel, it appeared within the globulin zone.

After charcoal treatment of the plasma, the quantity and elution volume of the high MW immunoreactive component was not modified, and the small GIR fraction could not be detected.

As shown in Figure 2, trypsin treatment of a globu-

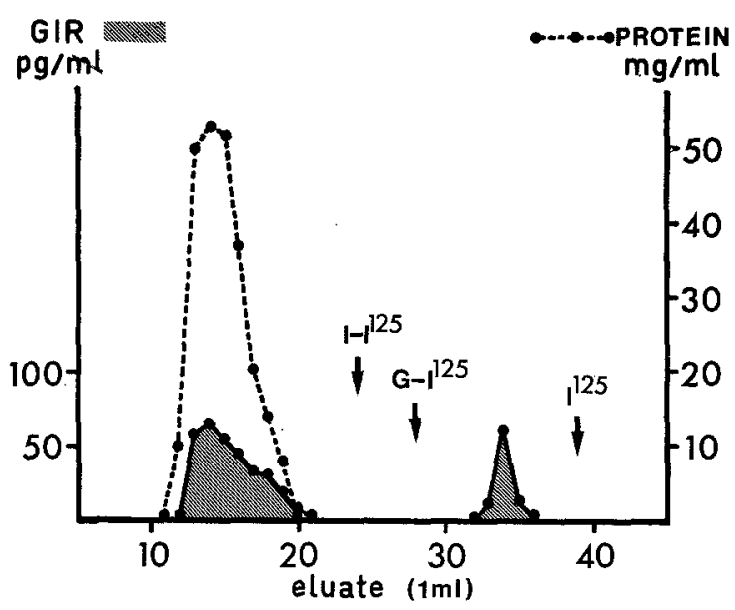

Fig. 1. Chromatographic pattern on Bio Gel P-30 of the glucagon immunoreactivity (GIR) present in the basal plasma of a totally pancreatectomized patient (concentration: $110 \mathrm{pg} / \mathrm{ml}$ ). The arrows indicate the elution volume of the radioactive markers (insulin$I^{125}: I-I^{125}$; glucagon- $I^{125}:$ G-I $\left.{ }^{125} ; I^{125}\right)$. The shaded area represents the GIR, and the broken line the protein content of the eluates

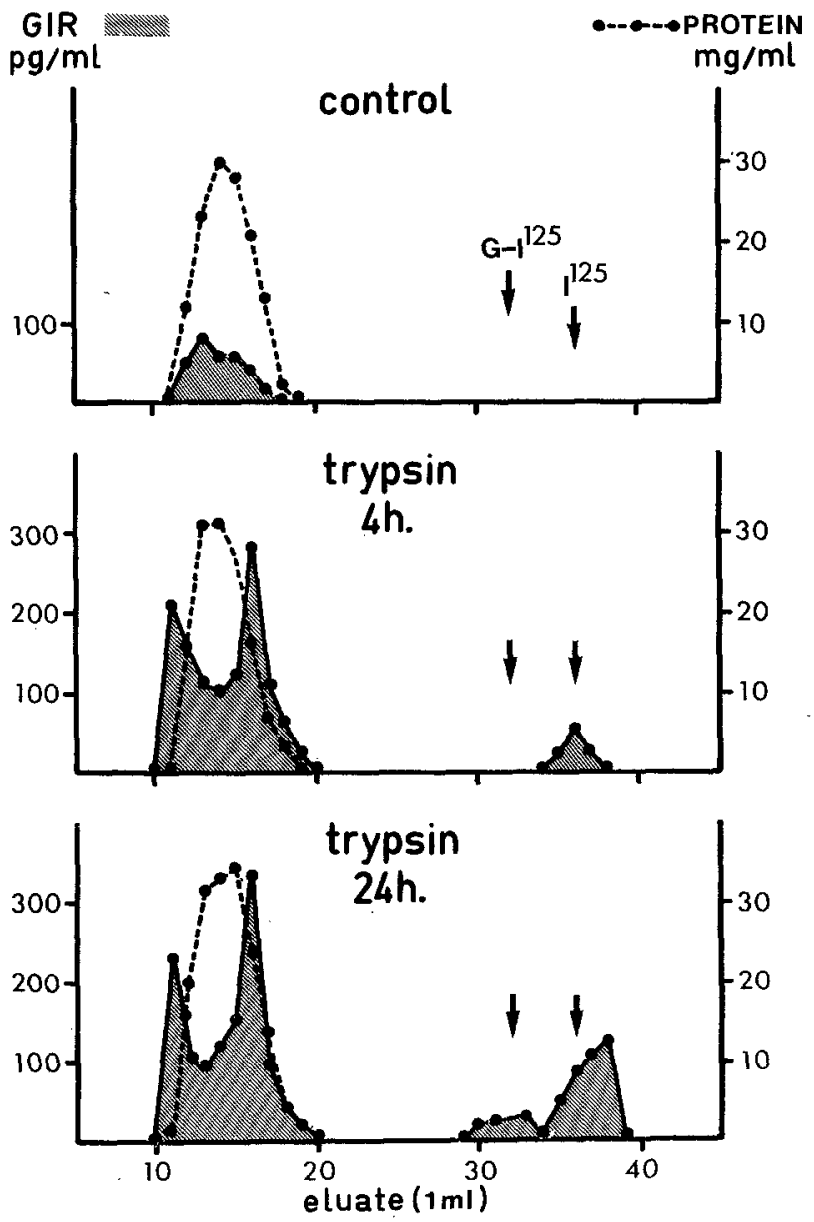

Fig. 2. Trypsin treatment of a globulin preparation containing the protein-sized GIR fraction. Filtration on Sephadex G-100 
lin preparation containing the protein-sized GIR fraction induced a split of the original, single, immunoreactive peak, an increase in the GIR area, and the appearance of glucagon immunoreactivity in the zones of the glucagon and iodine markers, when filtered through Sephadex G-100. Further characterization on Bio Gel P-30 of the elution volume of the trypsin-produced small GIR peak, showed it to run after the glucagon $-\mathrm{I}^{125}$ tracer $(\mathrm{MW}=2000)$.

\section{Discussion}

Analysis of the plasma from a totally pancreatectomized patient using antiserum $30 \mathrm{~K}$, has demonstrated the presence of normal GIR concentrations $(80-100 \mathrm{pg} / \mathrm{ml})$. Our data are in accordance with those of Müller et al. [13] who, using the same antiserum, observed basal GIR levels of $80 \mathrm{pg} / \mathrm{ml}$ and 85 $\mathrm{pg} / \mathrm{ml}$ in two pancreatectomized patients. However, they are in frank disagreement with the report of Gerich et al. [14] who, employing antiserum $30 \mathrm{~K}$ in a similar radioimmunological system, reported that the plasma glucagon level of a totally depancreatized subject was undetectable.

Neither arginine nor glucose affected fasting GIR values, thus strongly suggesting the absence of functioning pancreatic or extrapancreatic A-cells. Filtration of whole plasma on Bio Gel P-30 showed no GIR in the $3500 \mathrm{MW}$ elution volume, further supporting the lack of true glucagon. Large glucagon immunoreactivity (LGI), the candidate precursor of glucagon [12], was also not found, again implying the lack of glucagon synthesis.

In depancreatized dogs, normal or elevated plasma GIR levels, as determined with antisera considered to be specific for glucagon, have been reported by a number of investigators $[3,4,5,6]$. In fact, a 3500 MW material, biologically and immunometrically identical to pancreatic glucagon, has been extracted from porcine duodenum and, furthermore, A-cells ultrastructurally indistinguishable from those present in the pancreatic islets have been found in dog gastric fundus and duodenum [8]. The upper gastrointestinal tract appears therefore to be the source of true glucagon after pancreatectomy in dogs.

The failure to detect true glucagon in our patient, might represent a species difference or be a consequence of the surgical procedure, which could have removed the gastrointestinal A-cells. However, gel filtration of the plasma on Bio Gel P-30 clearly revealed the presence of a GIR peak in the protein region. This moiety ran with the globulins on
Sephadex G-100, was not absorbable by charcoal and its trypsin treatment yielded smaller GIR fractions. Therefore, from these criteria it can be assumed that it is identical to BPG of normal subjects, thus suggesting an extrapancreatic source for this component. An extrainsular origin of fraction IV seems apparent from our data as well.

Finally, as noticed by Unger and Orci [15], endogenous hyperglycaemia had never been observed in the absence of glucagon. The presence of fasting hyperglycaemia in the pancreatectomized subject we have studied, indicates that insulin deficiency by itself suffices to raise blood sugar to diabetic levels. In support of this concept, a recent report by Barnes and Bloom [16] demonstrated fasting hyperglycaemia in five pancreatectomized patients in whom circulating glucagon was absent.

Acknowledgments. The surgical intervention of the patient we have studied was performed by Dr. José Luis Barros (Hospital Provincial de Madrid, C. S. P.F. F., Madrid) to whom we wish to express our gratitude for his cooperation. The expert technical assistance of Ms. Inés Garcia, Ms. Ana Ramírez, and Ms. Begoña Samper is gratefully appreciated.

\section{References}

1. Valverde, I., Villanueva, M. L., Lozano, I., Marco, J.: Presence of glucagon immunoreactivity in the globulin fraction of human plasma ("Big plasma glucagon"). J. clin. Endocr. 39, 1090-1098 (1974)

2. Weir, G. C., Knowlton, S. D., Martin, D. B.: High molecular weight glucagon-like immunoreactivity in plasma. J. clin. Endocr. 40, 296-302 (1975)

3. Vranic, M., Pek. S., Kawamori, R.: Increased "glucagon immunoreactivity" in plasma of totally depancreatized dogs. Diabetes 23, 905-912 (1974)

4. Matsuyama, T., Foa, P.P.: Plasma glucose, insulin, pancreatic and enteroglucagon levels in normal and depancreatized dogs. Proc. Soc. exp. Biol. (N. Y.) 147, 97-102 (1974)

5. Mashiter, K., Harding, P. E., Chou, M., Mashiter, G. D., Stout, J., Diamond, D., Ficld, J. B.: Persistent pancreatic glucagon but not insulin response to arginine in pancreatectomized dogs. Endocrinology 96, 678-693 (1975)

6. Dobbs, R., Sakurai, H., Sasaki, H., Faloona, G., Valverde, I., Baetens, D., Orci, L., Unger, R. H.: Glucagon: role in the hyperglycemia of diabetes mellitus. Science 187, 544-547 (1975)

7. Penhos, J. C., Ezequiel, M., Lepp, A., Ramey, E. R.: Plasma immunoreactive insulin (IRI) and immunoreactive glucagon (IRG) after evisceration with and without a functional liver. Diabetes 24, 637-640 (1975)

8. Sasaki, H., Rubalcava, B., Baetens, D., Blázquez, E., Srikant, C. B., Orci, L., Unger, R. H.: Identification of glucagon in the gastrointestinal tract. J. clin. Invest. 56, 135-145 (1975)

9. Marco, J., Calle, C., Román, D., Díaz-Fierros, M., Villanueva, 
M. L., Valverde, I.: Hyperglucagonism induced by glucocorticoid treatment in man. New Engl. J. Med. 288, 128-131 (1973)

10. Weir, G. C., Turner, R. C., Martin, D. B.: Glucagon radioimmunoassay using antiserum $30 \mathrm{~K}$ : Interference by plasma. Horm. Metab. Res. 5, 241-244 (1973)

11. Faloona, G. R., Unger, R. H.: Glucagon. In: Methods of hormone radioimmunoassay (eds. B. M. Jaffe, H. R. Behrman), pp. 317-330. New York: Academic Press, Inc. 1974

12. Rigopoulou, D., Valverde, I., Marco, J., Faloona, G., Unger, R. $\mathrm{H}$.: Large glucagon immunoreactivity in extracts of pancreas. J. biol. Chem. 245, 496-501 (1970)

13. Müller, W. A., Brennan, M. F., Tan, M. H., Aoki, T. T.: Studies of glucagon secretion in pancreatectomized patients. Diabetes 23, 512-516 (1974)

14. Gerich, J. E., Schneider, V., Dippe, S. E., Langlois, M., Noacco, C., Karam, J. E., Forsham, P. H.: Characterization of the gluca- gon response to hypoglycemia in man. J. clin. Endocr. 38, 77-82 (1974)

15. Unger, R. H., Orci, L.: The essential role of glucagon in the pathogenesis of diabetes mellitus. Lancet 1975 I, 14-16

16. Barnes, A. J., Bloom, S. R.: Pancreatectomized man: a model for diabetes without glucagon. Lancet 1976 I, 219-221

Received: April 26, 1976, and in revised form: August 11, 1976

Dr. M. L. Villanueva

Clinica Puerta de Hierro

Universidad Autónoma de Madrid

San Martin de Porres, 4

Madrid 35

Spain 